\title{
Energy consumption, capital expenditures, R\&D cost and company profitability: evidence from paper and allied industry
}

\author{
Andrius Zuoza ${ }^{1}$ \\ Vaida Pilinkiené ${ }^{2}$ \\ ${ }^{1}$ Lithuanian Energy Institute, \\ 3 Breslaujos St., \\ 44403 Kaunas, Lithuania \\ Email: andrius.zuoza@lei.lt \\ ${ }^{2}$ Kaunas University of Technology, \\ 50 Gedimino St., \\ 44029 Kaunas, Lithuania \\ Email: vaida.pilinkiene@ktu.lt
}

This paper aims to empirically examine the relations between energy consumption, $R \& D$ costs and capital expenditures on the profitability of manufacturing companies in the paper and allied industry. The main focus in this article is on the companies, which are operating in the manufacture of pulp from wood and the paper production industry. Multiple regression analysis was used to test if the energy consumption, $R \& D$ costs and capital expenditures significantly predict EBITDA profitability. The results of the regression analysis indicated that all used predictors explained $\left(\mathrm{R}^{2}\right) 35.7 \%$ of the company profitability variance $\left(\mathrm{R}^{2}=0.357, \mathrm{~F}(3 ; 80)=14.82\right.$, $p$-value $\left.<0.01\right)$. The performed regression analysis also shows that energy consumption has a significant contribution to the profitability of the company. The results also indicate that only energy consumption explains $12.1 \%$ of the profitability variance $\left(\mathrm{R}^{2}=0.121, \mathrm{~F}(1 ; 101)=13.86\right.$, $p$-value $=0.01)$. The results of the regression analysis show that EBITDA profitability will increase by about $3.7 \cdot 10-7 \%$ for each 1000 GJ energy consumed.

Keywords: energy consumption, capital expenditures, R\&D cost, company profitability, paper and allied industry

\section{INTRODUCTION}

The scientific interest in energy use and countries economic development [1] is on the agen$\mathrm{da}$ of some local [2] and international organisations [3,4]. The International Energy Agency (IEA) states that 'energy efficiency can bring many significant economic and environmental benefits' [3]. IEA refers that since 2000 the energy intensity (energy use per unit of gross val- ue-added) of the manufacturing industries in the OECD countries fell by $25 \%$. IEA also forecasts that, if manufacturing industries invest in energy efficiency innovation, then, till 2040, they could produce nearly twice as much gross-value from each unit of energy use [3].

However, some researches $[5,6]$ notice that there is still a gap in the literature regarding the influence of the consumed energy on the company financial performance. 
The European Commission founded that growing energy cost for the companies negatively affects their export possibilities. It also states that the growth in energy efficiency did not compensate for the increase in energy prices [7]. The findings regarding energy cost and export possibilities from the EU industry correspond to the findings from the US manufacturing sector [8].

In the Energy Efficiency Report for 2018 [3], IEA notices that in the business investments into industrial energy efficiency technologies compete for the capital with other investments, and decision-makers believe that they are riskier than other investments.

Thollander and Ottosson [9] perceive that the growth of energy efficiency increases company's financial performance. Feng et al. [6] provide the empirical evidence from China companies on the effect of fuel intensity on a company's profitability. It was found that a $1 \%$ increase in fuel intensity will rescue a net profit margin by $20 \%$. The recent study [10] from the Swedish pulp and paper industry investigated if firm characteristics (including the profit of the company) affect the energy efficiency of the company. The results of the Lewrence et al. [10] study showed a different correlation between company characteristics and energy use in different types of the mills. The results of this study also demonstrated that there was no correlation between the energy efficiency and profit of the company in the Swedish pulp and paper industry.

To evaluate company's financial results such indicators as sales, costs by different categories, operating profit, profit before tax, paid dividend amount, etc. are commonly used. However, when it comes to comparing different companies or the company's activity variation over time, the main focus is shifted on the efficiency of the company, which cannot be measured by absolute indicators. To characterize the efficiency of the company, profitability indicators are mainly used [11]. Profitability can be described as a measure of the company's ability to generate sales revenue and control its costs [12]. Furthermore, profitability shows not only the current situation but also a possible trend. Usual profitability indicators are categorized [13, $12,14,15]$ into two groups - revenue margins and assets return. Revenue margins are used to analyse the company's possibilities to earn profit from the main activity. As mentioned by a couple of researchers $[13,16]$, a ratio of the earnings before interest, taxes, depreciation and amortisation (EBITDA) and the total revenue (EBITDA margin) is one of the most important revenue indicators. Pech et al. state that the EBITDA margin is the most used profitability indicator by equity analysts [17]. Some conclusions about the influence of operating expenses on the company's profit can be made from EBITDA. A higher EBITDA margin indicates to analysts and managers that the financial risk of the company is lower.

Lee et al. showed [18] that reduced energy consumption (improved energy efficiency) in the aviation industry led to improved overall company profitability. Stehrer supposes that other cost components (labour costs, $\mathrm{R} \& \mathrm{D}$, innovation, business services, etc.) can be more important to the competitiveness of manufacture companies than energy costs [19].

The influence of capital expenditures on companies value is well discussed in the scientific literature [20-23]. There are various opinions regarding capital expenditure and profitability of the company. The Kerstein and Kim research results show that companies capital expenditure is positively related to future returns of the company [21]. Meanwhile, the empirical results from the research in the transport industry show that capital expenditures have a negative effect on the profitability of the carrier [24]. The results from the empirical experiment of Keassey and Moon show that the activity of decision-makers in terms of capital expenditure is based on the decision environment and awareness of individual reflections rather than on objective parameters (e.g. profitability, investment calculations) [23]. Capital expenditures are characterized as capital expenditures on property, plant and equipment [25]. Amir et al. show that in some industries, capital expenditures or R\&D costs are relevant to companies operating incomes [26].

As mentioned by some researchers $[3,9,10]$, pulp and paper manufacturing is one of the most energy-intensive industrial sectors, e.g. in 2016 the Sweden pulp and paper industry used $~ 51 \%$ of the total consumed industrial energy [27].

This paper aims to empirically examine the relations between energy consumption, $R \& D$ costs and capital expenditures on the profitability of 
the manufacture companies in the paper and allied industry.

In this paper, two null hypotheses were tested:

$\mathrm{H}_{1}$ : A higher level of energy consumption reduces the profitability of the company.

$\mathrm{H}_{2}$ : A higher level of energy consumption, $\mathrm{R} \& \mathrm{D}$ costs and capital expenditures reduces the profitability of the company.

\section{METHODOLOGY}

\section{Model and data}

The data for this research was collected from the Thomson Reuters Datastream for financial data and Asset4 ESG database [28]. In this paper, companies were selected by two criteria - accounting currency and declared energy consumption (1) and working industry (2). It was focused (1) on the companies, whose financial statements were presented in US dollars and which reported consumed total direct and indirect energy in the period from 2002 to 2016. Only companies, which were operating in paper and allied industry (SIC Division D, Major Group 26), were selected (2). This industry includes firms, which are working in pulps, paper and paperboard production and converted products sector [29]. The chosen period was dictated by data availability. The data sample consists of 44 companies and 104 records.

The classical profit function [30] for the company $i$ is described as the difference between the total revenue (TR) and total cost (TC) and can be expressed as

$$
\Pi_{i}=T R_{i}-T C_{i}=\Sigma p_{i} y_{i}-\Sigma w_{i} x_{i},
$$

where $\Pi$ is the profit of the company, $y$ is the number of company's sold services or products, $x$ is the needed resource for product and services production, $p$ is the prices of services or products, and $w$ is the costs of resources.

The total cost can also be expressed as follows:

$$
T C_{i}=F C_{i}+V C_{i}=F C_{i}+f\left(E p_{i}\right) E w_{i}
$$

Here $F C$ is the fixed cost of the company, $V C$ is the variable cost of the company, $E w$ is the energy price, and Ep is the needed energy amount for product and services production. Equation (2) demonstrates that the variable cost depends on the used energy amount for products production and the price of energy. It is possible to split the fixed cost (3) of the company to the sum of $R \& D$ costs (RD), capital expenditures (CE) and another cost $(\varepsilon)$ :

$$
\mathbf{F C}_{i}=R D_{i}+C E_{i}+\varepsilon_{i}
$$

It was assumed that companies are working in the competitive market and market prices for sold services and products are equal for all companies in the market. It was also assumed that energy price is identical for all companies in the market ( $p=$ const $;=$ const $)$. The last assumption is that the global market size for the end product is not changing $(y=$ const $)$. This implies that companies can achieve more profit only by increasing the efficiency of used energy. By referring to Equations (1), (2) and (3) the profit function can be written as follows:

$$
\Pi_{i}=\min _{E p}\left(f\left(E p_{i}\right) E w_{i}+R D_{i}+C E+\varepsilon_{i}\right) .
$$

In this paper to evaluate the company's profitability, the earnings before interest, taxes, depreciation and amortisation (EBITDA) margin were used. The EBITDA margin (ebitda_m) was calculated (5) by dividing the EBITDA and total revenue (TR):

$$
\text { ebitda_ } \mathrm{m}_{\mathrm{i}}=\frac{\text { EBITDA }_{\mathrm{i}}}{\mathrm{TR}_{\mathrm{i}}} .
$$

Here ebitda_m is the EBITDA margin, EBITDA is earnings before interest, taxes, depreciation and amortisation, TR is the total revenue, and $i$ is the company.

Among the other performance indicators, the EBITDA margin is one of the critical indicators, thus it provides information on the profitability of the company [31] and can be used to compare the profitability of different companies working in the same industry $[32,33]$. The EBITDA margin is a valuable indicator, especially by international standards, as different accounting regulations, tax laws or depreciation policies do not influence the calculation of the indicator [12]. As mentioned by Kaličanin et al. [34], the EBITDA margin also includes profits of previous periods. Such information 
on past companies results also suggests about the competence to be profitable in the future and also to achieve a positive cash flow.

The main disadvantage of EBITDA margin, as performance indicators, for comparison of companies profitability, is that, by forming joint ventures, it is possible to eliminate from income considerable cost blocks and raise EBITDA [35, 36].

The available data set determines that to estimate the model coefficients, the linear regression model should be used. The regression equation can be written as

$$
\text { ebitda_m } \mathrm{m}_{\mathrm{i}}=\beta_{0}+\beta_{1} E p_{i}+\beta_{2} R D_{i}+\beta_{3} C E_{i}+\varepsilon_{\mathrm{i}},
$$

where $\beta$ is the regression coefficient and $\varepsilon_{i}$ includes other costs and unobserved variables.

For comparison of the results, the simplified regression model (7) will also be presented:

$$
\text { ebitda_m } \mathrm{m}_{\mathrm{i}}=\beta_{0}+\beta_{1} E p_{i}+u_{i} .
$$

Here $u_{i}$ includes other unobserved variables.

To estimate the unknown parameters of the regression model, the ordinary least squares method was used.

The significance level ( $p$-value) for all statistical calculation was set by 0.05 .

All statistical computation and model buildings were done using the $R$ programming language (Version 3.5.2).

\section{Descriptive statistics of the variables}

In the data sample, $86 \%$ of the companies are based in the USA, and the rest come from Australia, Chile, China, South Africa, Turkey and the UK.

In the analysed data set, the average EBITDA margin was 0.179 (standard deviation $(S D)=$ 0.057), the companies consumed on average 70869349 GJ total direct and indirect energy
$(S D=58910$ 929), for R\&D companies spent on average USD $631184(S D=858822)$ and average capital expenditures were USD 38366241 $(S D=127826887)$. The other main descriptive statistic is shown in Table 1.

There are 16 missing values in the data set. Those missing values were excluded from the further data analysis. Four outliers were also excluded from the further data analysis. Due to the big difference in the scale of energy consumption, $\mathrm{R} \& \mathrm{D}$ costs and capital expenditures data Z-score was computed with the following formula [37]:

$$
z_{i}=\frac{\left(x_{i}-\bar{x}\right)}{s} .
$$

Here $z_{i}$ is the $Z$-score, $x_{i}$ is the observation value, $\bar{x}$ is the sample mean, and $s$ is the sample standard deviation.

The correlation between the EBITDA margin and energy consumption was 0.254 ( $p$-value $=$ 0.02 ), between the EBITDA margin and $R \& D$ costs it was 0.452 ( $p$-value $<0.01)$ and between the EBITDA margin and capital expenditures 0.461 ( $p$-value $<0.01)$.

The histograms of the data, pairwise data plots and correlation coefficients (Corr) [38] are shown in Fig. 1.

\section{RESULTS AND DISCUSSION}

Based on the regression model expressed by Equation (6), a multiple linear regression was calculated to predict the EBITDA margin based on energy consumption (Ep), capital expenditures (CE) and R\&D costs (RD), and also a simplified regression model expressed by Equation (7), single linear regression, was calculated to predict the EBITDA margin based on energy consumption (Ep). The results of the estimation for both regression models are shown in Table 2 .

Table 1. Descriptive statistics

\begin{tabular}{ccccccc}
\hline Variable & Obs & Mean & Std. Dev. & Min. & Max \\
\hline EBITDA margin & 103 & 0.179 & 0.057 & 0.065 & 0.373 \\
\hline Energy consumption $(E p)$ & 103 & 70869348 & 58910929 & 272 & 303688000 \\
\hline Capital expenditures (CE) & 103 & 38366241 & 127826887 & 13843 & 863221712 \\
\hline R\&D cost (RD) & 86 & 631184 & 858822 & 6900 & 3138674 \\
\hline
\end{tabular}




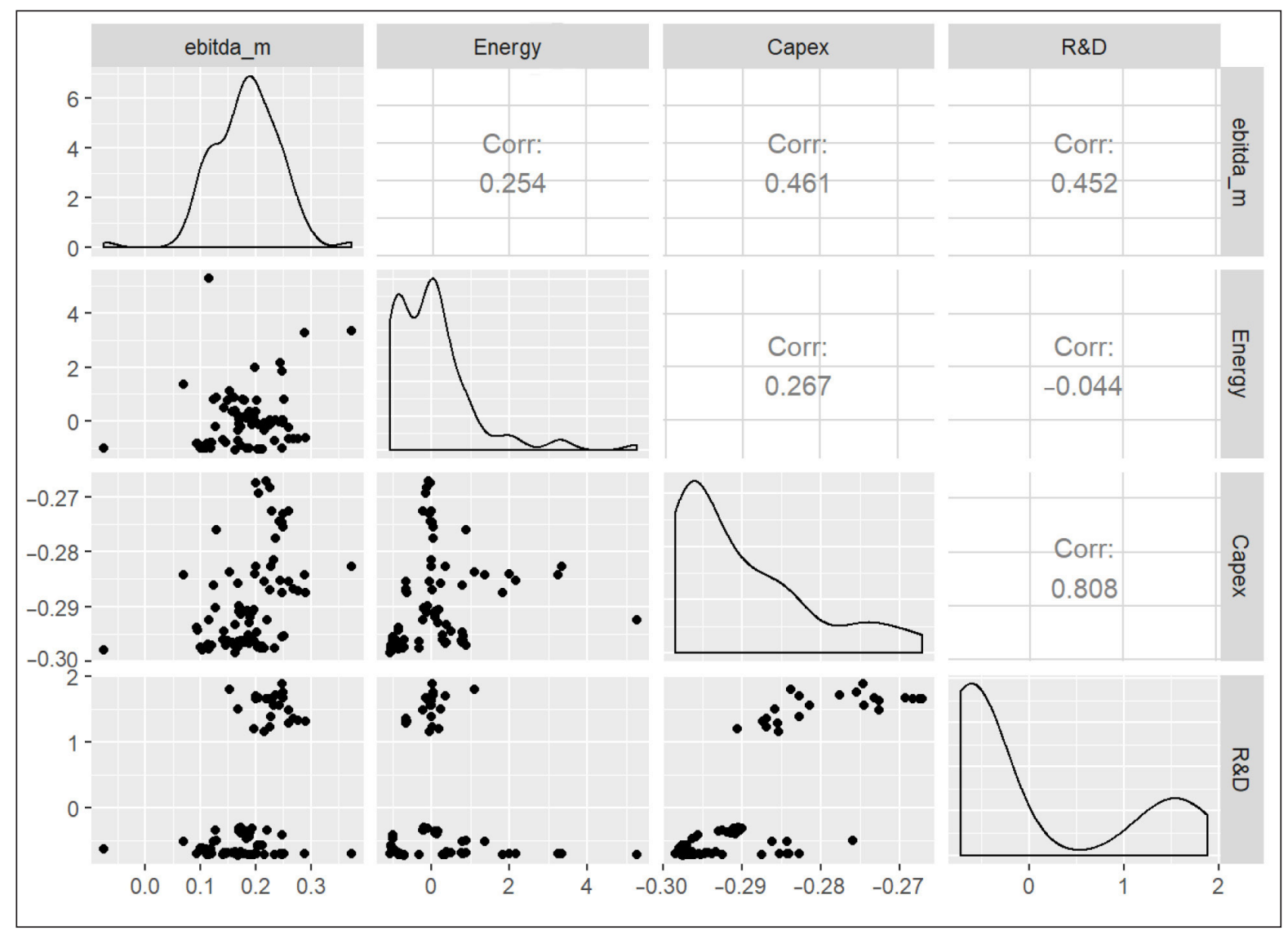

Fig. 1. Generalized pairs plot of the variables studied in the model

Table 2. Results of regression coefficients estimation

\begin{tabular}{|c|c|c|}
\hline & \multicolumn{2}{|c|}{ Dependent variable: } \\
\hline & \multicolumn{2}{|c|}{ EBITDA margin (ebitda_m) } \\
\hline & (1) & (2) \\
\hline Energy consumption (Ep) & $0.02^{* * *}(0.005)$ & $0.015^{* * *}(0.005)$ \\
\hline Capital expenditures (CE) & & $-0.001 \quad(0.01)$ \\
\hline$R \& D$ cost $(R D)$ & & $0.036^{* * *}(0.01)$ \\
\hline Constant & $0.179^{* * *}(0.005)$ & $0.184^{* * * *}(0.005)$ \\
\hline Observations & 103 & 84 \\
\hline $\mathrm{R}^{2}$ & 0.121 & 0.357 \\
\hline Adjusted R² & 0.112 & 0.333 \\
\hline Residual Std. Error & $0.05(d f=101)$ & $0.042(d f=80)$ \\
\hline F Statistic & $13.86^{* * *}(d f=1 ; 101)$ & $14.82^{* * *}(d f=3 ; 80)$ \\
\hline \multicolumn{3}{|l|}{ Notes: } \\
\hline 1. & \multicolumn{2}{|c|}{$p$-value $<0.1 i^{* *} \boldsymbol{p}$-value $<\mathbf{0 . 0 5} ;{ }^{* * *} p$-value $<0.01}$. \\
\hline 2. & \multicolumn{2}{|c|}{ Std. Error is shown in brackets. } \\
\hline
\end{tabular}

Both regression models are significant (model No. 1 - F $(1 ; 103)=13.86$, $p$-value $<0.01$; model No. $2-\mathrm{F}(3 ; 80)=14.82$, $p$-value $<0.01)$.
The complex regression model (based on Equation (6)) indicated that three predictors explained $35.7 \%$ of the EBITDA margin variance, 
and the simplified regression model (based on Equation (7)) showed that one predictor explained $12.1 \%$ of the EBITDA margin variance.

In both regression models energy consumption is a significant predictor; however, the value of the energy consumption predictor in the complex regression model $(\beta=0.015$, $p$-value $<0.01)$ is slightly lower than that in the simplified regression model $(\beta=0.02, p$-value $<0.01)$.

A positive and statistically significant value of the $\beta$ coefficient for energy consumption in the simplified regression model (1) points out a positive relationship between the energy consumption and the company's profitability. For this reason, the hypothesis $\mathrm{H}_{1}$ was rejected.

A positive and statistically significant value of the $\beta$ coefficient for energy consumption and $\mathrm{R} \& \mathrm{D}$ costs in the complex regression model (2) points out a positive relationship between them and the company's profitability. For this reason, the hypothesis $\mathrm{H}_{2}$ was rejected.

The only insignificant predictor is capital expenditures $(\beta=-0.001, p$-value $>0.05)$.

\section{CONCLUSIONS}

The presented paper examined the relationship between energy consumption, R\&D cost and capital expenditures and the profitability (EBITDA margin) of 44 manufacture companies in the paper and allied industry.

Positive and statistically significant correlations between the EBITDA margin and indicators of regression models was found. The correlation coefficient ( $r$ ) between the EBITDA margin and energy consumption was $r=0.254(=0.01)$, between the EBITDA margin and R\&D costs $r=0.45(p$-value $<0.01)$ and between the EBITDA margin and capital expenditures it was $r=0.46$ $(p$-value $<0.01)$.

The performed regression analysis shows that energy consumption has a contribution to the profitability of the company. The results of the regression indicated that the energy consumption explained $12.1 \%$ of the variance $(\mathrm{F}(1 ; 101)=13.86$, $p$-value $=0.01)$. For this reason, the hypothesis $\mathrm{H}_{1}$ was rejected. The $\beta$ coefficient for energy consumption in the simplified regression model (based on Equation (7)) shows that the EBITDA profitability will increase by about $3.7 \cdot 10^{-7} \%$ for each $1000 \mathrm{GJ}$ energy consumed. The findings of this paper do not match Lawrence conclusions.

The multiple regression analysis was used to test if the energy consumption, R\&D costs and capital expenditures significantly predict EBITDA profitability (the complex regression model is based on Equation (6)). The results of the regression indicated that the three predictors explained $35.7 \%$ of the variance $(\mathrm{F}(3 ; 80)=14.82$, $p$-value $<0.01)$. A positive and statistically significant value of the $\beta$ coefficient for energy consumption and $R \& D$ costs points out a positive relationship between them and the company's profitability. For this reason, the hypothesis $\mathrm{H}_{2}$ was rejected. The results of the complex regression analysis also show that capital expenditures have no significant influence on the profitability of the company. Such results partly correspond to the Keasey and Moon findings.

Received 20 January 2019 Accepted 5 December 2019

\section{References}

1. Csereklyei Z., Rubio-Varas M. D. M., Stern D. I. Energy and economic growth: The stylized facts. The Energy Journal. 2016. Vol. 37. P. 223-255.

2. European Commission. Energy efficiency. In: Energy. https://ec.europa.eu/energy/en/topics/energy-efficiency

3. International Energy Agency. Energy Efficiency 2018. 2018.

4. International Association for Energy Economics. https://www.iaee.org/en/inside/

5. Bergmann A., Rotzek J. N., Wetzel M., Guenther E. Hang the low-hanging fruit even lower - Evidence that energy efficiency matters for corporate financial performance. Journal of Cleaner Production. 2017. Vol. 147. P. 66-74.

6. Feng L., Fu T., Kutan A. M. Fuel intensity, access to finance and profitability: firm-level evidence from China. Emerging Markets Finance and Trade. 2018. Vol. 54. P. 3117-3130.

7. Crespo D. C. European Competitiveness Report 2014 - Helping Firms Grow. Publications Office of the European Union, 2014. 
8. Riker D. A. Energy Costs and Export Performance. International Trade Administration, Office of Competition and Economic Analysis, 2012.

9. Thollander P., Ottosson M. Energy management practices in Swedish energy-intensive industries. Journal of Cleaner Production. 2010. Vol. 18. P. 1125-1133.

10. Lawrence A., Karlsson M., Thollander P. Effects of firm characteristics and energy management for improving energy efficiency in the pulp and paper industry. Energy. 2018. Vol. 153. P. 825-835.

11. Shvachych G., Kholod E. Research of the enterprise profitability strategy. Baltic Journal of Economic Studies. 2017. Vol. 3. P. 451-456.

12. Berman K., Knight J., Case J. Financial Intelligence: A Manager's Guide to Knowing What the Numbers Really Mean. Brighton: Harvard Business Review Press, 2013.

13. Groppelli A. A., Nikbakht E. Finance. New York: Barron's Educational Series, 2000.

14. Nazir M. S., Afza T. Impact of aggressive working capital management policy on firms' profitability. IUP Journal of Applied Finance. 2009. Vol. 15. P. 19.

15. Rutkauskas A. V., Sūdžius V., Mackevičius V. Verslo finansu principai ir praktika. Vilnius: VGTU, 2009.

16. Gronskas V. Ekonomine analize. Kaunas: Technologija, 2005.

17. Trejo Pech C. O., Noguera M., White S. Financial ratios used by equity analysts in Mexico and stock returns. Contaduría y Administración. 2015. Vol. 60. P. 578-592.

18. Lee J. J., Lukachko S. P., Waitz I. A., Schafer A. Historical and future trends in aircraft performance, cost and emissions. Annual Review of Energy and the Environment. 2001. Vol. 26. P. 167-200.

19. Stehrer R. Energy Cost Shares and Energy Intensities in Manufacturing: Comparing the EU With Its Major External Competitors. The Vienna Institute for International Economic Studies, 2015.

20. Merchant K. A., Van der Stede W. A. Management Control Systems: Performance Measurement, Evaluation and Incentives. Pearson Education, 2007.

21. Kerstein J., Kim S. The incremental information content of capital expenditures. Accounting Review. 1995. P. 513-526.
22. Fama E. F., Miller M. H. The Theory of Finance. New York: Holt, Rinehart and Winston, 1972.

23. Keasey K., Moon P. Gambling with the house money in capital expenditure decisions: An experimental analysis. Economics Letters. 1996. Vol. 50. P. 105-110.

24. Wu W.-M., Huang D.-S. Modelling the profitability of container shipping lines: Theory and empirical evidence. Transport Policy. 2018. Vol. 72. P. 159-170.

25. Gordon L. A., Iyengar R. J. Return on investment and corporate capital expenditures: Empirical evidence. Journal of Accounting and Public Policy. 1996. Vol. 15. P. 305-325.

26. Amir E., Guan Y., Livne G. The association of $\mathrm{R} \& \mathrm{D}$ and capital expenditures with subsequent earnings variability. Journal of Business Finance \& Accounting. 2007. Vol. 34. P. 222-246.

27. Energy in Sweden - Facts and Figures. 2019. https:// www.energimyndigheten.se/en/news/2019/energy-in-sweden---facts-and-figures-2019-availablenow/

28. Thomson Reuters Datastream Asset 4 ESG Content. https://infobase.thomsonreuters.com/infobase/login/?next=/infobase/

29. SIC Division Structure. https://www.osha.gov/pls/ imis/sic_manual.html

30. Varian H. R. Intermediate Microeconomics: A Modern Approach. New York: W. W. Norton \& Co, 2010.

31. Vintila G., Nenu E. A. An analysis of determinants of corporate financial performance: Evidence from the Bucharest Stock Exchange listed companies. International Journal of Economics and Financial Issues. 2015. Vol. 5. P. 732-739.

32. Alcalde A., Lopes Fávero L. P., Takamatsu R. T. EBITDA margin in Brazilian companies. Variance decomposition and hierarchical effects. Contaduría y Administración. 2013. Vol. 58. P. 197-220.

33. EBITDA: A clear look. https://www.investopedia. com/articles/06/ebitda.asp

34. Kaličanin Đ., Veljković S., Bogetić Z. Brand orientation and financial performance nexus. Industrija. 2015. Vol. 43. P. 155-173.

35. Wiehle U., Diegelmann M., Deter H., Schömig P. N. 100 Finanzkennzahlen. Wiesbaden: Cometis Publishing GmbH \& Co. KG, 2011. 
36. Stumpp P. M. Putting EBITDA In Perspective. Moody's Special Comment. 2000.

37. Čekanavičius V., Murauskas G. Statistika ir jos taikymas. I tomas. Vilnius: TEV, 2000.

38. Emerson J. W., Green W. A., Schloerke B., Crowley J., Cook D., Hofmann H., Wickham H. The generalized pairs plot. Journal of Computational and Graphical Statistics. 2013. Vol. 22. P. 79-91.

Andrius Zuoza, Vaida Pilinkienè

RYŠYS TARP POPIERIAUS IR GIMININGŲ

PRAMONĖS ŠAKŲ İMONIŲ PELNINGUMO,

SUNAUDOTOS ENERGIJOS, KAPITALINIŲ IŠLAIDŲ, MOKSLINIŲ TYRIMŲ IR PLĖTROS

KAŠTŲ

Santrauka

Straipsnio tikslas - empiriškai ịvertinti sunaudotos energijos, kapitalinių išlaidų, mokslinių tyrimų ir eks- perimentinès plètros kaštų bei popieriaus ir giminingu pramonès šakų gamybinių įmonių pelningumo ryšį. Pagrindinis dèmesys šiame straipsnyje kreipiamas $\mathfrak{i}$ medienos ir popieriaus gamybos pramonès imones. Ryšiui tarp sunaudotos energijos, kapitalinių išlaidų, mokslinių tyrimų ir eksperimentinès plètros kaštų bei įmonių pelningumo tirti buvo naudotas daugialypès regresinès analizès metodas. Rezultatai rodo, kad $35,7 \%\left(\mathrm{R}^{2}\right)$ i̇monès pelningumo pokyčiu galima paaiškinti modelyje naudotais kintamaisiais $\left(\mathrm{R}^{2}=0,357\right.$, $\mathrm{F}(3 ; 80)=14,82, p$ val $<0,01)$. Šios analizès rezultatai taip pat atskleide, kad sunaudotos energijos kiekis turi reikšmingos įtakos įmonès pelningumui. Gauti rezultatai leidžia daryti išvadą, kad EBITDA pelningumas padidejja maždaug $3,7 \cdot 10^{-7} \%$, vertinant kiekvieną 1000 GJ sunaudotos energijos.

Raktažodžiai: sunaudota energija, kapitalinès išlaidos, mokslinių tyrimų ir plètros kaštai, pelningumas, popieriaus ir giminingų pramonès šakų ịmonès 